\section{Bavarian discontent threatens funding deal for institutes}

Munich. Bavaria, home to some of Germany's largest research centres, is threatening to pull out of a long-standing national agreement on the financing of research institutes if the federal government backs a plan requiring each Land (state) to pay a higher share of the costs of the Max Planck institutes it hosts.

This could mean renegotiating the funding systems for all of Germany's research organizations, including the Fraunhofer Society and the Max Planck Society (MPG). At present, the costs of each organization are divided between Germany's federal and 16 Länder governments, according to a fixed ratio.

In the case of the MPG, this ratio is 50:50. But, unlike the other three organizations involved, the MPG does not allow a host Land to pay the full Land share of an institutes' costs, so as to maintain its political independence. Instead, each Land pays into a common fund used to finance half the Land share of all MPG institutes. So a host Land pays directly only a quarter of the costs of its own institutes, limiting its influence in such an institute's fate.

Länder with few such institutes resent subsidizing those in other Länder,

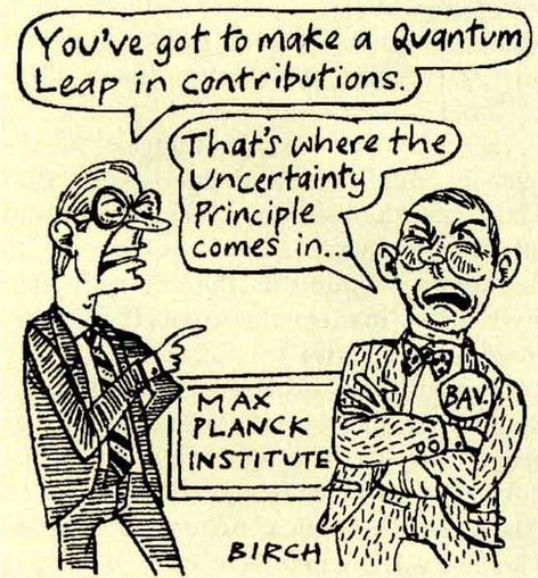

and earlier this month Länder prime ministers agreed at a meeting in Berlin to abandon the common fund by 1999 . Three Länder, Bavaria, Baden-Württemberg and Berlin, each with relatively large numbers of institutes, would face hefty bills, and voted against the move.

The decision has still to be approved by the federal government. But Bavarian prime minister Edmund Stoiber told the Berlin meeting that, unless a compromise is found, Bavaria may pull out of all joint funding agreements from 1999, forcing a major revision of research funding.

A.A.

\title{
Research centres face chaos after German ruling on tax
}

Munich. State-funded research institutes in Germany have been thrown into turmoil by a tax ruling that could require them to register as private companies, and severely limit their access to public funds.

The ruling was made by a federal taxation court in Munich, which decided that the DLR (Deutsche Forschungsanstalt für Luftund Raumfahrt), the national research centre for air and space research, must pay value added tax (VAT) on industrial research contracts at the full 15 per cent rate applicable to commercial companies. Organizations, including publicly funded research institutes, that do not make a 'profit' on the research they do, pay only 7 per cent.

It is more than 20 years since tax inspectors first demanded that DLR pay the tax at the full rate. The research centre refused to do so, while putting aside the difference, amounting to DM36 million (US\$25 million), in the hope that it would be allowed to keep these funds. Since 1985, the centre has been paying the full 15 per cent, hoping to win back excess payments in the courts.

But a lengthy legal battle, which started with the local finance office in Cologne in 1990, has now been lost. Last week DLR's case was rejected by Germany's highest financial court, requiring the centre to pay back the DM36 million. In theory, the decision could require all research institutes that carry out work for industry to raise the price of their contract research. This would seriously undermine their competitiveness; indeed, Erich Maaß, a member of the education and research working group of the Christian Democrats, the senior coalition partner in the Bundestag, points out that it would conflict with the government's wish to see closer links between academic institutions and industry (see Nature 4, 372; 1994).

There could be other consequences, too. First, the ruling might allow the government to demand back payments for tax from other applied research institutes. The KFA in Jülich, for example, which specializes in energy and environmental research, could face a bill of around DM20 million.

Second, in order that the tax may be collected, all research institutes with any income from industry would have to be legally defined as profit-making companies. This would make them liable for full VAT on all income - public as well as private, on basic as well as applied research - as well as various other taxes from which they are at present exempt. According to a spokeswoman from the Max Planck Society, for example, this would cost the society thousands of millions of marks per year.

The most dramatic consequence, according to Klaus Fleischmann, managing direc- tor of the Helmholtz Society, representing Germany's 16 national research centres, is that as private companies, the institutes would, under European Union competition laws, be allowed to receive no more than 25 per cent of their income from government.

This would mean that the financing of all public research institutes - including national research centres, Max Planck institutes, the applied research institutes of the Fraunhofer Society, and the 'Blue List' group - would need to be restructured, as they rely primarily on support from national and local governments. "The traditional system is threatened," warns Maaß.

No-one wants this to happen. Not only would it mean less money for research, but, as Hans-Ulrich Wiese, a member of the Fraunhofer Society board, points out, it would undermine the government's efforts to boost technology transfer. For example, if research institutes lost their status as public bodies, they would be unable to use staff paid out of public funds to carry out contract research, which would force up costs even further than the increased VAT.

Research organizations also claim that it is incongruous for the government to take back with one hand (the finance ministry) what it has given out with another (the research ministry). Beatrix Vierkorn-Rudolf, who runs the WBL, the newly created umbrella organization for Blue List institutes, finds it "absurd" that "at a time when the catch phrase is 'lean government', money should be shifted pointlessly between different ministries".

Although the court's decision was confirmed only last week, research organizations have been meeting with officials from the research ministry for several months to find a speedy way out of their dilemma.

A working group made up of representatives of these organizations, and headed by Fleischmann, claims that the only possible solution is a change in the law that would allow all research institutes to be considered as public bodies, irrespective of whether they have income from industry.

Such a move is supported by the Christian Democrats' education and research group. And last Monday (18 March), a group of expert officials from the finance ministry announced that they would be recommending to the finance minister that he should also support the idea. But, even if it were to be adopted by the government, it could not come into effect until the beginning of next year. Up to then, says Fleischmann, the finance ministry should institute a 'Nichtanwendungserlass' - meaning that the court ruling should not be enforced.

Alison Abbott \& Quirin Schiermeier 